\title{
Clinical, Hematological, and Biochemical Alterations in Olive Flounder Paralichthys olivaceus Following Experimental Infection by Vibrio scophthalmi
}

\author{
Guo Qiao ${ }^{1}$, Soo II Park ${ }^{2 *}$ and De-Hai Xu ${ }^{3}$ \\ ${ }^{1}$ Department of Aquaculture, National Fisheries Research \& Development Institute, Incheon 400-420, Korea \\ ${ }^{2}$ Department of Aquatic Life Medicine, Pukyong National University, Busan 608-737, Korea \\ ${ }^{3}$ US Department of Agriculture, Agricultural Research Service, Aquatic Animal Health Research Unit, Auburn, AL 36832, USA
}

\begin{abstract}
Hematological analysis can provide crucial information for monitoring the health of fish. However, there is no current information available regarding hematological changes in olive flounder following infection by Vibrio scophthalmi. In this study, hematological and biochemical alterations were determined in olive flounder infected by the high virulence strain (HVS) and low virulence strain (LVS) of $V$. scophthalmi. Survival in serum, skin mucus, and macrophages of olive flounder was also compared between the HVS and LVS. The results demonstrated that the hematocrit value in infected fish declined from $23.4 \%$ at $0 \mathrm{~h}$ to $18.0 \%$ at $168 \mathrm{~h}$ post infection. The total protein concentration in fish infected with the HVS was significantly higher than in fish infected with the LVS and a non-infected control. Lysozyme activity was significantly different between infected and control fish. The HVS survived in serum and cell numbers increased substantially, while cell numbers of the LVS in serum decreased. These changes in hematological characteristics in fish infected by $V$. scophthalmi can be used as an effective and sensitive index to monitor the physiological and pathological conditions of fish. The survival and reproduction of $V$. scophthalmi in host serum, skin mucus, and macrophages play a major role in systemic infection and can serve as a virulence indicator for different strains.
\end{abstract}

Key words: Vibrio scophthalmi, Virulent strain, Olive flounder, Hematology

\section{Introduction}

Vibrio scophthalmi is considered to be an opportunistic pathogen of flat fish, primarily infecting olive flounder and turbot (Wang et al., 2004; Jo et al., 2006; Qiao et al., 2012a). Olive flounder become more sensitive to infection by $V$. scophthalmi under stressful conditions (Qiao et al., 2012a). The virulence factors of $V$. scophthalmi have been well studied. Qiao et al. (2012b) investigated the pathogenicity of $V$. scophthalmi using high and low virulence strains (HVS and LVS, respectively), and suggested that both strains produced a slime layer and biofilm. The level of biofilm production is positively associated with the pathogenicity of $V$. scophthalmi and susceptibility to antibiotics. Superoxide dismutase (SOD) activity of the HVS was higher than the LVS. Extracellular products (ECP) of the HVS showed higher pathogenicity to olive flounder as compared with the LVS. ECP demonstrated naphtol-AS-BI-phosphohydrolase, lipase, gelatinase, and leucine arylamidase activity. The extracellular $\mathrm{O}_{2}^{-}$overflow and intracellular $\mathrm{O}_{2}{ }^{-}$concentration of macrophages induced by HVS were lower than those induced by LVS. Nitric oxide production was significantly higher in the HVS than in the LVS (Qiao, 2011).

Generally, variations in hematological parameters are re-
Open Access http://dx.doi.org/10.5657/FAS.2012.0233

This is an Open Access article distributed under the terms of the Creative Commons Attribution Non-Commercial License (http://creativecommons. org/licenses/by-nc/3.0/) which permits unrestricted non-commercial use, distribution, and reproduction in any medium, provided the original work is properly cited.
Received 6 July 2012; $\quad$ Revised 8 August 2012;

Accepted 21 August 2012

*Corresponding Author

E-mail: parksi@pknu.ac.kr 
lated to the fish species, age, sexual maturity, and health conditions (Blaxhall, 1972; Hrubec et al., 2000; Jamalzadeh et al., 2009). Normal ranges for various hematological parameters in fish have been established by different studies of fish physiology and pathology (Blaxhall, 1972; Ram Bhaskar and Srinivasa Rao, 1989; Hrubec et al., 2000; Martins et al., 2008). Hematological parameters can be affected by bacterial infection (Martins et al., 2008), parasitic infection (Ghiraldelli et al., 2006), and poor water quality (Ram Bhaskar and Srinivasa Rao, 1989). Hematological tests and the analysis of serum constituents provide crucial information for monitoring the health of fish (Aldrin et al., 1982). Specifically, these approaches provide reliable information on metabolic disorders, deficiencies, and health status before they become disease problems in cultivated fish. Regular monitoring of the hematological parameters of farmed fish can prevent losses due to fish diseases in aquaculture (Ram Bhaskar and Srinivasa Rao, 1989). Currently, there is no information available regarding hematological changes in olive flounder following $V$. scophthalmi infection. In this study, a hematological analysis of olive flounder following $V$. scophthalmi infection was performed, including determination of hematocrit (Hct), hemoglobin ( $\mathrm{Hb})$, total protein (TP), albumin (Alb), globulin (Glo), albumin:globulin (A:G) ratio, aspatate aminotransferase (AST), alanine aminotransferase (ALT), glucose concentration, superoxide dismutase (SOD), lysozyme, and bacteriolytic activities of serum. In addition, the survival of $V$. scophthalmi in serum, skin mucus, and macrophages was investigated in vitro.

\section{Materials and Methods}

\section{Bacterial strains}

Two strains of $V$. scophthalmi (HVS A19008 and LVS A19010) with different levels of virulence were used in this study. The HVS A19008 was isolated from a kidney, and LVS A19010 was obtained from a spleen, of a diseased olive flounder at the Jeju and Pohang farms, respectively. The HVS A19008 was highly virulent and LVS A19010 had a relatively low virulence to olive flounder (Qiao et al., 2012a). These strains were preserved at $-80^{\circ} \mathrm{C}$ at the Fish Disease and Prevention Laboratory, Pukyong National University, Korea. Prior to experiments, bacteria were routinely grown in tryptic soy broth (TSB) or tryptic soy agar supplemented with $2 \%$ $\mathrm{NaCl}(\mathrm{ST})$ at $27^{\circ} \mathrm{C}$ for $24 \mathrm{~h}$ and pathogenicity was checked according to challenge tests (Qiao et al., 2012a).

\section{Experimental olive flounder}

Normal olive flounder, with an average body weight of $47.28 \mathrm{~g}$ and body length of $17.01 \mathrm{~cm}$, were obtained from a farm in Geoje Island and maintained in an aquaria at approxi- mately 30 practical salinity units (psu), $18-20^{\circ} \mathrm{C}$ and $\mathrm{pH} 8.0$ $( \pm 0.2)$ for two weeks prior to the experiment. The fish were fed with commercial fish pellets (National Federation of Fisheries Cooperatives Feed, Korea) until they were used for the experiment.

\section{Challenge test}

Pathogenicity of these two strains was determined in vivo (Nieto et al., 1984). Bacterial suspensions were prepared by culturing the strains in TSB supplemented with $2 \% \mathrm{NaCl}$ at $25^{\circ} \mathrm{C}$ for $24 \mathrm{~h}$, washing with sterilized physiological saline (PS), and then adjusting to the appropriate concentration of $10^{7}$ $(\mathrm{CFU}) / \mathrm{mL}$ with PS. Each fish was injected intraperitoneally with $0.2 \mathrm{~mL}$ of bacterial suspension. Fish in the control group were injected with $0.2 \mathrm{~mL}$ of PS. The fish were observed daily for 14 days post bacterial challenge. All mortalities and clinical signs were recorded daily. Moribund or freshly dead fish were collected to isolate the inoculated bacteria and confirm the causative pathogen. Three fish in each group were sampled at $0,1,3,9,12,24,72$, and 168 hours post infection (hpi) for hematological tests.

\section{Hematological study of olive flounder following V. scophthalmi infection}

\section{Hematological examination}

The fish were sacrificed with a lethal dose of benzocaine anesthetic (CAS, Canada). Fish blood was drawn from the caudal vein with a syringe treated with an anticoagulant. Samples were then centrifuged at $300 \mathrm{~g}$ for $10 \mathrm{~min}$ at $4^{\circ} \mathrm{C}$ to obtain the plasma for hematological measurements. $\mathrm{Hb}$ concentration was measured by a blood Hb kit (Asan Pharm Co., Seoul, Korea) and the Hct value was determined using a microcapillary reader at $1 \mathrm{~h}$. The samples were kept at $-70^{\circ} \mathrm{C}$ until use and no samples were frozen more than once.

\section{Biochemical examination}

Peripheral blood was drawn with a syringe without anticoagulant and allowed to clot for $1 \mathrm{~h}$ at room temperature and $2 \mathrm{~h}$ at $4^{\circ} \mathrm{C}$. After centrifugation at $300 \mathrm{~g}$ for $10 \mathrm{~min}$ at $4^{\circ} \mathrm{C}$, serum was collected for measurement of biochemical parameters. The biochemical tests were conducted using assay kits (Asan Pharm Co., Korea) for TP, Alb, Glo, A:G ratio, AST, ALT, SOD and glucose concentration. Lysozyme activity was assayed using the turbidimetric method. The turbidimetric assay uses the lysis of Micrococcus lysodeikticus (ATCC 4698; Sigma, St. Louis, MO, USA) to determine the lysozyme activity and egg-white lysozyme (LYS 702.5; Bioshop Canada Inc., Burlington, ON, Canada) as a standard (Sankaran and Gurnani, 1972). Briefly, $100 \mu \mathrm{L}$ of phosphate buffered saline (PBS, pH 6.2) was added to each well of a 96-well plate, and $100 \mu \mathrm{L}$ of serum was added to the first well of each row. Twofold serial dilutions were then made in the remaining wells 
with PBS. One hundred microliters of $0.4 \mathrm{mg} / \mathrm{mL} M$. lysodeikticus in PBS ( $\mathrm{pH}$ 6.2) was added to each well. The enzyme kinetics were measured with a microtiter plate reader at $590 \mathrm{~nm}$ every $10 \mathrm{~min}$ for $40 \mathrm{~min}$ and the last measurement was conducted at $60 \mathrm{~min}$. Lysozyme activity was recorded as 1 unit, which caused a decrease in absorbance of 0.001 per min. The bacteriolytic test followed the method of Pruzanski (1973) with Escherichia coli JM089 (ATCC 29522) was chosen to monitor the bactericidal activity in the serum of normal and challenged olive flounder individuals. E. coli JM089 was grown in $200 \mathrm{~mL}$ of Luria Bertani (LB) medium for $20 \mathrm{~h}$ at $37^{\circ} \mathrm{C}$ with shaking at $200 \mathrm{rpm}$. Bacterial concentration was adjusted to an optical reading of 0.5 at $540 \mathrm{~nm}$ and added to the serum solution at a 1:1 ratio (bacterial suspension:serum dilution). Sterilized LB medium was added to the serum solution as a negative control. The mixture was placed on an orbital incubator for $1 \mathrm{~h}$ at $25^{\circ} \mathrm{C}$ and $200 \mathrm{rpm}$. Results were recorded as an increase of the absorbance.

\section{Survival of $V$. scophthalmi in fish serum and skin mucus}

Serum and skin mucus of olive flounder were prepared following the techniques described by Bordas et al. (1996). The bacterial cells were suspended in fresh serum or skin mucus $(1: 1, \mathrm{v}: \mathrm{v})$ and adjusted to $1 \times 10^{6} \mathrm{CFU} / \mathrm{mL}$ bacterial cells. One hundred microlitres of each sample was removed at $0,1,3,6$, and $18 \mathrm{~h}$ after incubation at $25^{\circ} \mathrm{C}$ and 10 -fold serial dilutions of PBS were spread on ST plates. The survival rate of strains in serum or skin mucus was defined as the number of viable bacteria after the co-culture was divided by an initial bacterial count as described by Leung et al. (1994).

\section{Intracellular survival of V. scophthalmi in macro- phages in vitro}

\section{Macrophage monolayer preparation}

Monolayers of head kidney macrophages from olive flounder individuals were prepared as described by Secombes (1990) with slight modifications. The head kidney was removed, ground, and filtered through a sterile nylon mesh with L-15 medium (Gibco, Grand Island, NY, USA) containing 2\% fetal bovine serum (FBS, Gibco), $100 \mathrm{IU} / \mathrm{mL}$ penicillin, 100 $\mu \mathrm{g} / \mathrm{mL}$ streptomycin, and $10 \mathrm{U} / \mathrm{mL}$ heparin (Sigma). The cell suspension was layered onto a $34-51 \%$ Percoll density gradient in siliconized tubes on ice and centrifuged at $400 \mathrm{~g}$ for 30 $\min$ at $4^{\circ} \mathrm{C}$. The band of macrophages lying above the Percoll interface were collected and washed with L-15 medium containing $0.1 \%$ FBS. The cell pellet was resuspended in L-15 medium supplemented with $0.1 \%$ FBS, $100 \mathrm{IU} / \mathrm{mL}$ penicillin, and $100 \mu \mathrm{g} / \mathrm{mL}$ streptomycin. The viability of cells was determined by staining with $0.5 \%$ trypan blue (Hudson and Hay, 1989). The macrophages could be used if the survival rate was more than $95 \%$ after separation. The non-adherent cells were washed off after 3 to $5 \mathrm{~h}$ at $18^{\circ} \mathrm{C}$ and the remaining monolayers were maintained with L-15 medium (containing 5\% FBS, $100 \mathrm{IU} / \mathrm{mL}$ penicillin, and $100 \mu \mathrm{g} / \mathrm{mL}$ streptomycin) and incubated at $18^{\circ} \mathrm{C}$ for 1 to 3 days before use.

\section{Intracellular survival of $\boldsymbol{V}$. scophthalmi in macrophages}

$V$. scophthalmi was added to the plate with macrophage monolayers at a 10:1 ratio (bacteria cell number:macrophage number). The plates were centrifuged at $50 \times g$ for $5 \mathrm{~min}$ to allow the bacteria to come in contact with the cells. Bacteria were removed and $200 \mu \mathrm{L}$ of fresh L-15 medium containing 3 $\mu \mathrm{g} / \mathrm{mL}$ of norfloxacin was then added. The infected cell monolayers were incubated for two more hours to completely kill residual extracellular and attached bacteria. The monolayers were then resuspended with L-15 medium containing 5\% FBS and $3 \mu \mathrm{g} / \mathrm{mL}$ norfloxacin to prevent the growth of bacteria released from ruptured and infected cells. Plates were incubated at $20^{\circ} \mathrm{C}$ and cells were lysed at $0,3,6,12$, and $18 \mathrm{~h}$ with $0.1 \%$ Triton X-100. The intracellular bacteria released were quantified by plating serial dilutions of the lysate. The numbers of CFU and the percentage invasion for each strain at different incubation times was calculated. The L-15 medium supplemented with $3 \mu \mathrm{g} / \mathrm{mL}$ norfloxacin without cells served as a media control.

\section{Statistical analysis}

All values for the hematological and biochemical parameters were expressed as a mean \pm standard deviation (SD). Hematological parameters in fish of different treatment groups were analyzed by analysis of variance (ANOVA) using the SPSS version 17.0 (SPSS Inc., Chicago, IL, USA). $P$-values of 0.05 or less were considered to be statistically significant.

\section{Results}

\section{Pathogenicity assays}

Clinical signs in olive flounder were similar between fish infected both experimentally and naturally and included darkening skin, distended abdomen, hemorrhages of muscles, liver, and intestine, ascites, and hypertrophy of the spleen and kidney. The inoculated strains could be reisolated from the liver, spleen, kidney, and ascites of dead individuals.

\section{Hematological alterations of the olive flounder following V. scophthalmi infection}

\section{Hematological analysis}

The effects of $V$. scophthalmi infection on hematological parameters in olive flounder are shown in Table 1. The Hct value in fish infected by both the HVS and LVS decreased gradually post infection and was significantly different when 
Table 1. Hematological changes in olive flounder Paralichthys olivaceus following infection by different strains of Vibrio scophthalmi

\begin{tabular}{|c|c|c|c|c|c|c|c|c|c|}
\hline \multirow{2}{*}{ Ch } & \multirow{2}{*}{ Grp } & \multicolumn{8}{|c|}{ Hours post injection (hpi) } \\
\hline & & $\mathbf{0}$ & 1 & 3 & 9 & 12 & 24 & 72 & 168 \\
\hline \multirow[t]{3}{*}{ Het } & HVS & $23.5 \pm 1.4$ & $21.7^{\mathrm{b}} \pm 0.4$ & $20.4^{\mathrm{a}} \pm 0.7$ & $19.5^{\mathrm{c}} \pm 0.8$ & $18.4^{\mathrm{c}} \pm 1.2$ & $19.3^{\mathrm{c}} \pm 0.2$ & $18.5^{\mathrm{c}} \pm 0.7$ & $18.0^{\mathrm{b}} \pm 0.6$ \\
\hline & LVS & $23.7 \pm 1.0$ & $23.3^{\mathrm{a}} \pm 0.7$ & $22.2 \pm 0.6$ & $21.3^{\mathrm{b}} \pm 0.4$ & $19.4^{\mathrm{b}} \pm 1.1$ & $21.4^{\mathrm{ab}} \pm 1.0$ & $21.9^{\mathrm{b}} \pm 1.0$ & $22.9^{\mathrm{a}} \pm 1.4$ \\
\hline & Cont & $24.2 \pm 2.0$ & $22.9^{\mathrm{a}} \pm 1.2$ & $22.9 \pm 1.1$ & $23.3^{\mathrm{a}} \pm 2.1$ & $22.4^{\mathrm{a}} \pm 1.0$ & $22.4^{\mathrm{a}} \pm 2.3$ & $23.4^{\mathrm{a}} \pm 1.5$ & $23.5^{\mathrm{a}} \pm 0.5$ \\
\hline \multirow[t]{3}{*}{ Hem } & HVS & $2.90 \pm 0.1$ & $2.92^{\mathrm{a}} \pm 0.2$ & $2.90 \pm 0.3$ & $2.95 \pm 0.3$ & $2.93 \pm 0.1$ & $2.90 \pm 0.1$ & $2.87 \pm 0.1$ & $2.80^{\mathrm{a}} \pm 0.1$ \\
\hline & LVS & $2.88 \pm 0.3$ & $2.90^{\mathrm{b}} \pm 0.1$ & $2.90 \pm 0.2$ & $2.93 \pm 0.1$ & $2.92 \pm 0.0$ & $2.92 \pm 0.1$ & $2.88 \pm 0.1$ & $2.90^{\mathrm{b}} \pm 0.0$ \\
\hline & Cont & $2.88 \pm 0.1$ & $2.90^{\mathrm{b}} \pm 0.1$ & $2.90 \pm 0.2$ & $2.96 \pm 0.2$ & $2.86 \pm 0.1$ & $2.88 \pm 0.1$ & $2.86 \pm 0.1$ & $2.86^{b} \pm 0.2$ \\
\hline \multirow[t]{3}{*}{ Glu } & HVS & $74.0 \pm 2.3$ & $58.4^{\mathrm{a}} \pm 2.6$ & $65.9^{\mathrm{a}} \pm 3.3$ & $67.6^{\mathrm{a}} \pm 1.2$ & $63.3^{\mathrm{a}} \pm 2.1$ & $86.7^{\mathrm{a}} \pm 2.5$ & $50.7^{\mathrm{a}} \pm 0.1$ & $54.6^{\mathrm{a}} \pm 0.5$ \\
\hline & LVS & $73.3 \pm 3.6$ & $54.0^{\mathrm{b}} \pm 2.1$ & $64.0^{\mathrm{b}} \pm 2.4$ & $55.9^{b} \pm 3.4$ & $64.3^{\mathrm{b}} \pm 2.1$ & $61.9^{b} \pm 3.4$ & $45.2^{\mathrm{b}} \pm 1.2$ & $63.0^{\mathrm{b}} \pm 3.2$ \\
\hline & Cont & $74.7 \pm 2.2$ & $52.3^{\mathrm{c}} \pm 1.3$ & $62.2^{\mathrm{c}} \pm 3.5$ & $53.9^{b} \pm 3.3$ & $44.8^{c} \pm 2.3$ & $61.4^{\mathrm{b}} \pm 4.1$ & $54.1^{\mathrm{c}} \pm 1.4$ & $57.8^{\mathrm{c}} \pm 0.5$ \\
\hline \multirow[t]{3}{*}{$\mathbf{T P}$} & HVS & $4.7 \pm 0.2$ & $4.6 \pm 0.1$ & $5.2^{\mathrm{a}} \pm 0.1$ & $5.68^{\mathrm{a}} \pm 0.1$ & $5.86^{\mathrm{a}} \pm 0.3$ & $5.8^{\mathrm{a}} \pm 0.1$ & $4.64^{\mathrm{a}} \pm 0.1$ & $4.9^{\mathrm{a}} \pm 0.2$ \\
\hline & LVS & $4.7 \pm 0.2$ & $4.6 \pm 0.1$ & $4.5^{\mathrm{b}} \pm 0.2$ & $4.7^{\mathrm{b}} \pm 0.2$ & $4.9^{\mathrm{b}} \pm 0.1$ & $4.8^{\mathrm{b}} \pm 0.1$ & $4.6^{b} \pm 0.2$ & $4.6^{b} \pm 0.2$ \\
\hline & Cont & $4.7 \pm 0.3$ & $4.6 \pm 0.2$ & $4.5^{\mathrm{b}} \pm 0.1$ & $4.64^{\mathrm{b}} \pm 0.1$ & $4.7^{\mathrm{c}} \pm 0.1$ & $4.7^{\mathrm{b}} \pm 0.2$ & $4.7^{\mathrm{c}} \pm 0.1$ & $4.5^{\mathrm{bc}} \pm 0.2$ \\
\hline \multirow[t]{3}{*}{ Alb } & HVS & $2.4 \pm 0.2$ & $2.3 \pm 0.2$ & $2.2^{\mathrm{a}} \pm 0.1$ & $2.3^{\mathrm{a}} \pm 0.2$ & $2.4 \pm 0.1$ & $2.4^{\mathrm{a}} \pm 0.1$ & $2.4^{\mathrm{a}} \pm 0.1$ & $2.26^{\mathrm{a}} \pm 0.2$ \\
\hline & LVS & $2.4 \pm 0.1$ & $2.3 \pm 0.1$ & $2.3^{\mathrm{b}} \pm 0.1$ & $2.4^{\mathrm{ab}} \pm 0.1$ & $2.5 \pm 0.1$ & $2.5^{\mathrm{b}} \pm 0.1$ & $2.3^{\mathrm{b}} \pm 0.3$ & $2.4^{\mathrm{b}} \pm 0.1$ \\
\hline & Cont & $2.4 \pm 0.1$ & $2.3 \pm 0.2$ & $2.3^{\mathrm{a}} \pm 0.1$ & $2.4^{\mathrm{b}} \pm 0.1$ & $2.7 \pm 0.1$ & $2.5^{\mathrm{b}} \pm 0.0$ & $2.4^{\mathrm{a}} \pm 0.1$ & $2.4^{\mathrm{b}} \pm 0.1$ \\
\hline \multirow[t]{3}{*}{ Glo } & HVS & $2.3 \pm 0.0$ & $2.3 \pm 0.1$ & $3.0^{\mathrm{a}} \pm 0.1$ & $3.3^{\mathrm{a}} \pm 0.2$ & $3.5^{\mathrm{a}} \pm 0.1$ & $3.4^{\mathrm{a}} \pm 0.1$ & $2.2^{\mathrm{a}} \pm 0.1$ & $2.6^{\mathrm{a}} \pm 0.3$ \\
\hline & LVS & $2.3 \pm 0.1$ & $2.3 \pm 0.1$ & $2.2^{\mathrm{b}} \pm 0.1$ & $2.4^{\mathrm{b}} \pm 0.1$ & $2.5^{\mathrm{b}} \pm 0.1$ & $2.3^{\mathrm{b}} \pm 0.1$ & $2.2^{\mathrm{bc}} \pm 0.1$ & $2.3^{\mathrm{b}} \pm 0.2$ \\
\hline & Cont & $2.3 \pm 0.2$ & $2.3 \pm 0.0$ & $2.2^{\mathrm{c}} \pm 0.1$ & $2.2^{\mathrm{c}} \pm 0.1$ & $2.0^{\mathrm{ac}} \pm 0.1$ & $2.2^{\mathrm{c}} \pm 0.1$ & $2.3^{\mathrm{c}} \pm 0.1$ & $2.2^{\mathrm{c}} \pm 0.1$ \\
\hline \multirow[t]{3}{*}{$A: G$} & HVS & $1.0 \pm 0.0$ & $1.0 \pm 0.0$ & $0.8^{\mathrm{a}} \pm 0.0$ & $0.7^{\mathrm{a}} \pm 0.0$ & $0.7^{\mathrm{a}} \pm 0.1$ & $0.7^{\mathrm{a}} \pm 0.0$ & $0.8^{\mathrm{a}} \pm 0.0$ & $0.9^{\mathrm{a}} \pm 0.0$ \\
\hline & LVS & $1.0 \pm 0.1$ & $1.0 \pm 0.1$ & $1.1 \pm 0.1$ & $1.0 \pm 0.1$ & $1.0 \pm 0.0$ & $1.1 \pm 0.0$ & $1.0 \pm 0.1$ & $1.0 \pm 0.0$ \\
\hline & Cont & $1.0 \pm 0.1$ & $1.0 \pm 0.0$ & $1.0 \pm 0.1$ & $1.1 \pm 0.1$ & $1.1 \pm 0.1$ & $1.1 \pm 0.1$ & $1.0 \pm 0.0$ & $1.1 \pm 0.0$ \\
\hline \multirow[t]{3}{*}{ AST } & HVS & $9.9 \pm 0.2$ & $10.4 \pm 0.0$ & $9.2^{\mathrm{a}} \pm 0.2$ & $10.5^{\mathrm{a}} \pm 0.4$ & $9.9 \pm 0.5$ & $8.3^{\mathrm{a}} \pm 0.2$ & $8.4^{a} \pm 0.2$ & $7.1^{\mathrm{a}} \pm 0.3$ \\
\hline & LVS & $9.9 \pm 0.1$ & $10.7 \pm 1.0$ & $10.2^{\mathrm{ab}} \pm 0.6$ & $11.5^{\mathrm{b}} \pm 0.1$ & $9.7 \pm 0.2$ & $8.8^{\mathrm{a}} \pm 0.1$ & $8.2^{\mathrm{ab}} \pm 0.1$ & $9.3^{b} \pm 0.1$ \\
\hline & Cont & $9.9 \pm 0.1$ & $10.3 \pm 0.0$ & $10.3^{\mathrm{a}} \pm 0.1$ & $9.7^{\mathrm{ac}} \pm 0.3$ & $10.0 \pm 0.6$ & $10.5^{\mathrm{b}} \pm 0.3$ & $9.9^{c} \pm 0.2$ & $10.8^{\mathrm{bc}} \pm 0.3$ \\
\hline \multirow[t]{3}{*}{ ALT } & HVS & $6.3 \pm 0.0$ & $6.5 \pm 0.0$ & $6.2 \pm 0.1$ & $5.8^{\mathrm{a}} \pm 0.1$ & $6.5^{\mathrm{a}} \pm 0.1$ & $5.9^{\mathrm{a}} \pm 0.1$ & $6.3^{\mathrm{a}} \pm 0.1$ & $6.8^{\mathrm{a}} \pm 0.1$ \\
\hline & LVS & $6.3 \pm 0.0$ & $6.2 \pm 0.4$ & $6.1 \pm 0.1$ & $6.0^{\mathrm{b}} \pm 0.1$ & $6.3^{\mathrm{b}} \pm 0.0$ & $6.1^{\mathrm{ab}} \pm 0.0$ & $6.1^{\mathrm{ab}} \pm 0.0$ & $6.2^{b} \pm 0.0$ \\
\hline & Cont & $6.3 \pm 0.3$ & $6.1 \pm 0.2$ & $6.1 \pm 0.0$ & $6.2^{c} \pm 0.0$ & $5.8^{\mathrm{bc}} \pm 0.0$ & $5.7^{\mathrm{bc}} \pm 0.1$ & $6.5^{\mathrm{c}} \pm 0.1$ & $6.3^{b} \pm 0.0$ \\
\hline \multirow[t]{3}{*}{ SOD } & HVS & $81.6 \pm 1.1$ & $86.7^{\mathrm{a}} \pm 1.3$ & $71.8^{\mathrm{a}} \pm 1.3$ & $85.2^{\mathrm{a}} \pm 3.8$ & $65.3^{\mathrm{a}} \pm 1.4$ & $64.1^{\mathrm{a}} \pm 1.7$ & $67.8^{\mathrm{a}} \pm 0.6$ & $97.2^{\mathrm{a}} \pm 0.2$ \\
\hline & LVS & $79.6 \pm 1.0$ & $110.4^{\mathrm{a}} \pm 2.3$ & $75.8^{\mathrm{b}} \pm 0.4$ & $82.2^{\mathrm{a}} \pm 0.8$ & $81.9^{\mathrm{b}} \pm 1.0$ & $89.7^{\mathrm{b}} \pm 1.6$ & $79.3^{b} \pm 3.2$ & $78.1^{b} \pm 0.7$ \\
\hline & Cont & $78.2 \pm 2.0$ & $86.4^{\mathrm{b}} \pm 1.2$ & $97.8^{\mathrm{c}} \pm 0.9$ & $93.2^{\mathrm{ab}} \pm 1.3$ & $127.9^{\mathrm{c}} \pm 1.0$ & $99.6^{\mathrm{c}} \pm 1.6$ & $95.4^{\mathrm{c}} \pm 1.6$ & $74.4^{\mathrm{c}} \pm 2.3$ \\
\hline \multirow[t]{3}{*}{ Lys } & HVS & $66.4^{\mathrm{ab}} \pm 1.0$ & $116.4^{\mathrm{a}} \pm 1.2$ & $90.6^{a} \pm 6.4$ & $68.4^{a} \pm 0.7$ & $121.4^{\mathrm{a}} \pm 1.2$ & $35.3^{\mathrm{a}} \pm 0.3$ & $29.9^{\mathrm{a}} \pm 0.6$ & $32.7^{\mathrm{a}} \pm 1.0$ \\
\hline & LVS & $64.3^{\mathrm{a}} \pm 0.8$ & $84.3^{\mathrm{b}} \pm 1.0$ & $72.0^{\mathrm{b}} \pm 0.6$ & $119.3^{\mathrm{b}} \pm 1.6$ & $31.5^{\mathrm{b}} \pm 1.3$ & $42.2^{\mathrm{b}} \pm 1.5$ & $40.5^{\mathrm{a}} \pm 0.8$ & $52.7^{\mathrm{b}} \pm 1.6$ \\
\hline & Cont & $64.3^{\mathrm{a}} \pm 0.6$ & $52.4^{\mathrm{c}} \pm 1.9$ & $41.3^{\mathrm{c}} \pm 0.3$ & $66.3^{\mathrm{a}} \pm 0.8$ & $65.2^{c} \pm 3.9$ & $62.6^{\mathrm{c}} \pm 2.1$ & $61.5^{\mathrm{b}} \pm 0.9$ & $63.5^{\mathrm{c}} \pm 1.1$ \\
\hline \multirow[t]{3}{*}{ Bac } & HVS & $1.5^{\mathrm{a}} \pm 0.0$ & $1.7^{\mathrm{a}} \pm 0.2$ & $1.7^{\mathrm{a}} \pm 0.2$ & $1.7^{\mathrm{a}} \pm 0.3$ & $2.3^{\mathrm{a}} \pm 0.1$ & $2.3^{\mathrm{a}} \pm 0.1$ & $1.9^{\mathrm{a}} \pm 0.2$ & $1.0^{\mathrm{a}} \pm 0.1$ \\
\hline & LVS & $1.6^{\mathrm{a}} \pm 0.1$ & $2.3^{\mathrm{b}} \pm 0.2$ & $1.5^{\mathrm{b}} \pm 0.1$ & $1.6^{\mathrm{b}} \pm 0.1$ & $1.7^{\mathrm{b}} \pm 0.1$ & $2.6^{\mathrm{b}} \pm 0.5$ & $1.6^{\mathrm{b}} \pm 0.2$ & $1.4^{\mathrm{b}} \pm 0.1$ \\
\hline & Cont & $1.8^{\mathrm{b}} \pm 0.1$ & $1.9^{c} \pm 0.3$ & $1.6^{\mathrm{ab}} \pm 0.1$ & $1.8^{\mathrm{a}} \pm 0.2$ & $1.9^{\mathrm{c}} \pm 0.1$ & $1.6^{\mathrm{c}} \pm 0.1$ & $1.8^{\mathrm{c}} \pm 0.1$ & $1.6^{\mathrm{c}} \pm 0.2$ \\
\hline
\end{tabular}

Values are provided as mean \pm SD. Within a given characteristics, means followed by different superscript letters are significantly different $(P<0.05)$.

Ch, characteristics; Grp, groups; HVS, high virulence strain A19008; LVS, low virulence strain A19010; Cont, control; Hct, hematocrit (\%); Hem, hemoglobin (g/ $\mathrm{dL})$; Glu, glucose concentration (mg/dL); TP, total protein ( $\mathrm{g} / \mathrm{dL})$; Alb, albumin $(\mathrm{g} / \mathrm{dL}) ;$ Glo, globumin $(\mathrm{g} / \mathrm{dL}) ; A: G$, albumin:globumin ratio; AST, aspatate aminotransferase value (kar/mL); ALT, alanine aminotransferase value (kar/mL); SOD, superoxide dismutase activity $(\mathrm{U} / \mathrm{mL}) ;$ Lys, lysozyme activity $(\mathrm{U} / \mathrm{mL}) ; \mathrm{Bac}$, bactericidal activity (fold change of absorbance). 


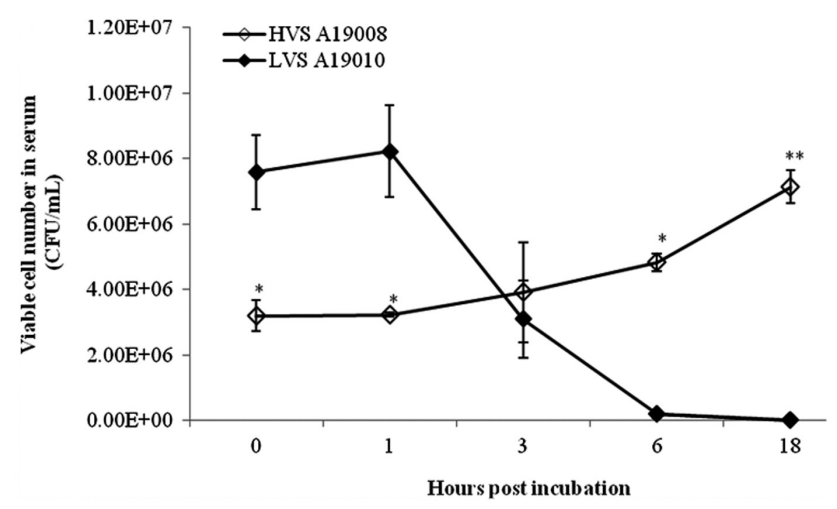

Fig. 1. Survival of Vibrio scophthalmi high and low virulence strains (HVS A19008 and LVS A19010) in the serum of olive flounder Paralichthys olivaceus. CFU, colony forming units.

compared to fish in the control group. In fish infected with the HVS, the Hct value declined to $18.0 \%$ compared to the control group (23.5\%) at $168 \mathrm{hpi}$. The $\mathrm{Hb}$ concentration increased to $2.95 \mathrm{~g} / \mathrm{dL}$ at $9 \mathrm{hpi}$, and decreased to $2.80 \mathrm{~g} / \mathrm{dL}$ at $168 \mathrm{hpi}$ which was similar to the value at $0 \mathrm{~h}$.

\section{Biochemical examination}

Serum biochemical values are shown in Table 1 . The glucose concentration decreased significantly in the HVS and LVS infection groups compared to the control group from 1 to 24 hpi. TP concentration in the HVS infection group was significantly higher than in the LVS and control groups from 3 to $24 \mathrm{hpi}$. TP concentration increased to $5.86 \mathrm{~g} / \mathrm{dL}$ at $12 \mathrm{hpi}$, as compared with $4.7 \mathrm{~g} / \mathrm{dL}$ that in the control fish. The A:G ratio in the HVS infection group decreased significantly after 3 hpi and was significantly lower when compared to the control fish over the period from 3 to 168 hpi. Fish infected with the HVS had an A:G ratio of 0.69 at $12 \mathrm{hpi}$, significantly lower than the ratio of $1.03 \mathrm{~A}: \mathrm{G}$ recorded in the control fish. The AST value and SOD activity in fish infected with the HVS also declined significantly after 12 hpi compared to those in the control group. ALT activity was not significantly different between infected and control groups. Lysozyme activity was significantly different between infected and control groups. Lysozyme activity in the HVS and LVS infected groups was

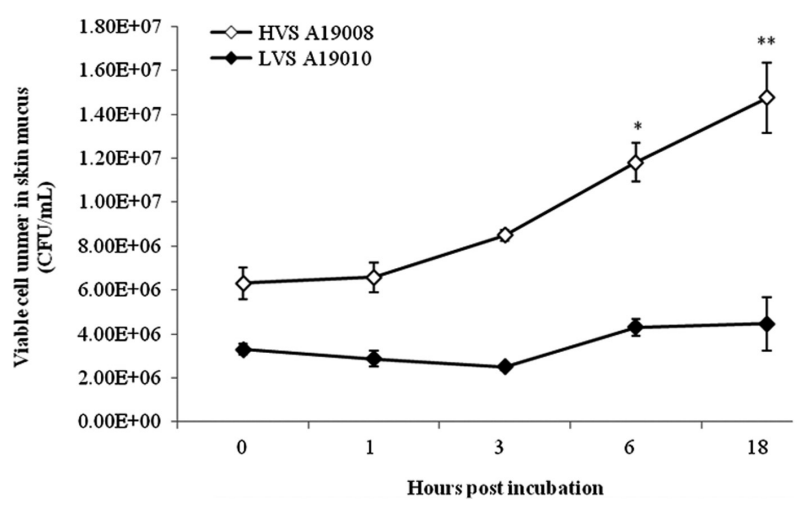

Fig. 2. Survival of Vibrio scophthalmi high and low virulent strains (HVS A19008 and LVS A19010) in the skin mucus of olive flounder Paralichthys olivaceus. CFU, colony forming units.

enhanced significantly from 1 to $12 \mathrm{hpi}$ and then decreased from 24 to 168 hpi compared to the control fish.

\section{Bactericidal activity of serum}

As shown in Table 1, bactericidal activity of serum in the HVS and LVS infected groups increased over time post infection and reached the highest values (2.3-2.6) at $24 \mathrm{hpi}$, which was significantly higher than the corresponding value in the control fish (1.6).

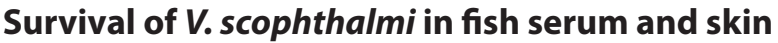 mucus}

The HVS could survive in fresh serum and cell numbers increased by approximately $2 \log$ units at 18 hpi (Fig. 1). The LVS showed serum sensitivity and cell numbers decreased below the detection limit. The HVS was able to survive and replicate in skin mucus with cell numbers increasing from $7.33 \times$ $10^{5}$ to $1.59 \times 10^{6} \mathrm{CFU} / \mathrm{mL}$, whereas the LVS maintained cell numbers at the original levels in skin mucus (Fig. 2).

\section{Intracellular survival of V. scophthalmi in macro- phages in vitro}

As shown in Table 2, the HVS was internalized in macro-

Table 2. Intracellular survival of Vibrio scophthalmi in olive flounder Paralichthys olivaceus macrophages in vitro

\begin{tabular}{|c|c|c|c|c|c|}
\hline \multirow{2}{*}{ Strains } & \multicolumn{5}{|c|}{ Percent changes in CFU counts at different incubation time (h) } \\
\hline & $\mathbf{0}$ & 3 & 6 & 12 & 18 \\
\hline Recovered HVS A19008 & $0 \pm 0$ & $197.2 \pm 25.6$ & $498.6 \pm 67.3$ & $878.4 \pm 54.3$ & $1,462.7 \pm 80.9$ \\
\hline Free HVS A19008 & $0 \pm 0$ & $309.7 \pm 41.3$ & $137.1 \pm 18.6$ & $-20.8 \pm 14.7$ & $-89.6 \pm 20.4$ \\
\hline Recovered LVS A19010 & $0 \pm 0$ & $208.6 \pm 69.8$ & $477.4 \pm 45.6$ & $762.3 \pm 66.7$ & $1,042.3 \pm 76.4$ \\
\hline Free LVS A19010 & $0 \pm 0$ & $332.8 \pm 39.7$ & $159.3 \pm 29.1$ & $-41.4 \pm 31.5$ & $-94.4 \pm 31.7$ \\
\hline
\end{tabular}

Values represent the mean percent change of colony forming units (CFU) counts ( \pm SD) at different incubation time.

CFU, colony forming units; HVS, high virulence strain; LVS, low virulence strain. 
phages and cell numbers increased significantly from $0 \%$ to $197.2 \%, 498.6 \%, 878.6 \%$, and $1,462.7 \%$ after incubation for $3,6,12$, and $18 \mathrm{~h}$, respectively, despite the presence of norfloxacin in the media. In contrast, cell numbers in media without macrophages, but with norfloxacin, declined by $20.8 \%$ and $89.6 \%$ at 12 and $18 \mathrm{~h}$, respectively, when compared to cells at $0 \mathrm{~h}$. For the LVS, cell numbers increased by $208.6 \%, 477.4 \%$, $762.3 \%$, and $1042.3 \%$ after incubation for $3,6,12$, and $18 \mathrm{~h}$, respectively. Cell numbers of the LVS in medium with norfloxacin without macrophages declined $41.4 \%$ and $94.4 \%$ at 12 and $18 \mathrm{~h}$, respectively, when compared to time $0 \mathrm{~h}$. The HVS could survive and multiply in macrophages better than the LVS.

\section{Discussion}

Hematological characteristics are important for fish and can be used as an effective and sensitive index to monitor physiological and pathological conditions (Kori-Siakpere et al., 2005). In this study, TP concentration in the serum of olive flounder in the infected groups was significantly higher than that of control fish, which was consistent with observations made by Lee (2005). Lee (2005) found that TP concentration in fish injected with different concentrations of ECP extracted from Edwardsiella tarda, increased significantly until $168 \mathrm{hpi}$. Whereas Alb and the A:G ratio were significantly reduced in infected groups compared to a control group. Alb decreased as it is a negative acute phase protein and decreases in concentration following an inflammatory stimulus. The slight increase of glucose concentration in the infected groups was in accordance with that of olive flounder individuals infected by E. tarda ECP (Lee, 2005). The increase in glucose might be due to the increased rate of lipolysis as an alternative energy source during the infection (Ghanem and Abdel-Hamid, 2010) or the autoimmune response in the host induced by bacterial infection similar to a virus infection in mammals (Clark, 2003; Ghanem and Abdel-Hamid, 2010).

AST and ALT are jointly known as transaminases and are associated with inflammation or liver injury. AST is also found in many other organs in addition to the liver, including kidneys, muscles, and the heart. ALT is found primarily in the liver and high levels of ALT are almost always indicative of liver problems. In this study, ALT was observed to increase, indicating liver damage. Moreover, the ALT:AST ratio may also provide useful information regarding the extent and cause of liver disease, because most liver diseases are characterized by greater elevations of ALT than AST.

Lysozyme is a cationic enzyme that breaks down $\beta-1,4$ glycosidic acids and N-acetyl-glucosamine in the peptidoglucan of bacterial cell walls. It plays an important role in the bio-defense system against Gram-positive and Gram-negative bacteria (Alexander and Ingram, 1992). In this study, there were significant changes in the lysozyme activity of infected fish compared to the control fish. The infected fish were significantly stimulated before $12 \mathrm{hpi}$ and lysozyme activity reached a high level within a short period of time after infection. The bactericidal activity in infected fish also reached a high level before 72 hpi, suggesting that lysozyme levels could be correlated with phagocytic activity. The bactericidal activity of serum has been well recognized as one of the key mechanisms for clearing bacteria from fish (Ellis, 2001). In this study, the bactericidal activity in infected fish could not be maintained at a high level near the end of the experiment (168 hpi), probably due to the reduction in lysozyme secretion. Robertsen et al. (1990) demonstrated an enhanced protection against fish bacterial infection and confirmed a correlation with an increase in serum lysozyme, phagocytic, and bactericidal activity in head kidney phagocytes.

The HVS was able to survive and replicate in the serum of olive flounder individuals, whereas the LVS was unable to survive. This suggests that the survival and reproduction of $V$. scophthalmi in host serum plays a major role in systemic infection. According to Han et al. (2006), all virulent strains of E. tarda were able to survive and proliferate in serum, whereas the avirulent strain was susceptible to serum bactericidal activity. Similarly, survival ability in fish mucus or serum has been used as an indicator of virulence in $V$. harveyi, A. hydrophila, and Flavobacterium psychrophilum (Leung et al. 1994; Wiklund and Dalsgaard, 2002; Won and Park, 2008).

The results regarding the number of intracellular viable cells of bacterial strains revealed that both the HVS and LVS were capable of invasion and replication within macrophages in vitro and no significant difference in the bacterial number ingested per macrophage was observed between the HVS and LVS. Booth et al. (2006) noted that the bacterial number of the virulent $E$. ictaluri increased 2.6, 5.1, and 7.1 fold after 4, 8, and $12 \mathrm{~h}$ of incubation within channel catfish macrophages, respectively, suggesting E. ictaluri can survive and replicate within macrophages. The replication of the HVS within macrophages in vitro was faster than the replication of LVS, which might be related to the stronger resistance of HVS against macrophage-mediated killing through higher SOD activity. Therefore, the ability to survive and replicate within macrophages is a virulence factor in pathogenic bacteria.

In summary, this study evaluated hematological and biochemical alterations for olive flounder infected by $V$. scophthalmi and compared the survival between the HVS and LVS of $V$. scophthalmi in serum, skin mucus, and macrophages of olive flounder individuals. The results clearly demonstrated a significant difference in hematological characteristics between fish infected by $V$. scophthalmi and uninfected control fish, and between fish infected by two $V$. scophthalmi strains of different virulence (HVS and LVS). These changes in hematological characteristics in fish infected by $V$. scophthalmi could be used as an effective index to monitor the physiological and pathological conditions of fish. The survival and re- 
production of $V$. scophthalmi in host serum, skin mucus, and macrophages could also serve as a virulence indicator for different $V$. scophthalmi strains.

\section{Acknowledgments}

This work was supported by the Project "Environmentalfriendly Aquaculture Technology using BFT (Biofloc Technology)" (RP-2012-AQ-071), National Fisheries Research \& Development Institute (NFRDI), Republic of Korea.

\section{References}

Aldrin JF, Messager JL and Laurencin FB. 1982. La biochimie clinique en aquaculture. Interet et perspective. CNEXO Actes Colloq 14, 291-326.

Alexander JB and Ingram GA. 1992. Non-cellular and non-specific defense mechanisms of fish. Annu Rev Fish Dis 2, 249-279.

Blaxhall PC. 1972. The haematological assessment of the health of freshwater fish. J Fish Biol 4, 593-604.

Booth NJ, Elkamel A and Thune RL. 2006. Intracellular replication of Edwardsiella ictaluri in channel catfish macrophages. J Aquat Anim Health 18, 101-108.

Bordas MA, Balebona MC, Zorrilla I, Borrego JJ and Moriñigo MA. 1996. Kinetics of adhesion of selected fish-pathogenic Vibrio strains of skin mucus of gilt-head sea bream Sparus aurata L. Appl Environ Microbiol 62, 3650-3654.

Clark Z. 2003. Diabetes mellitus in a 6-month-old Charolais heifer calf. Can Vet J 44, 921-922.

Ellis AE. 2001. The immunology of teleosts. In: Fish Pathology. 3rd ed. Robert RJ, ed. W.B. Saunders, London, GB, pp.133-150.

Ghanem MM and Abdel-Hamid OM. 2010. Clinical, haematological and biochemical alterations in heat intolerance (panting) syndrome in Egyptian cattle following natural foot-and-mouth disease (FMD). Trop Anim Health Prod 42, 1167-1173.

Ghiraldelli L, Martins ML, Yamashita MM and Jerônimo GT. 2006. Ectoparasites influence on the haematological parameters of Nile tilapia and carp cultured in the State of Santa Catarina, South Brazil. J Fish Aquat Sci 1, 270-276.

Han HJ, Kim DH, Lee DC, Kim SM and Park SI. 2006. Pathogenicity of Edwardsiella tarda to olive flounder Paralichthys olivaceus (Temminck \& Schlegel). J Fish Dis 29, 601-609.

Hrubec TC, Cardinale JL and Smith SA. 2000. Hematology and plasma chemistry reference intervals for cultured tilapia Oreochromis hybrid. Vet Clin Pathol 29, 7-12.

Hudson L and Hay FC. 1989. Practical Immunology. Blackwell, London, GB, p. 507.

Jamalzadeh HR, Keyvan A, Ghomi MR and Gherardi F. 2009. Comparison of blood indices in healthy and fungal infected Caspian salmon Salmo trutta caspius. Afr J Biotechnol 8, 319-322.

Jo MR, Kim MC and Song CB. 2006. Development of a rapid diagnosis kit for Vibrios associated with the farmed olive flounder Paralichthys olivaceus in Jeju Island. J Fish Pathol F3.

Kori-Siakpere O, Ake JEG and Idoge E. 2005. Haematological characteristics of the African snake head Parachanna obscura. Afr J Biotechnol 4, 527-530.

Lee DC. 2005. Effect of Edwardsiella tarda ECPs on immune function in olive flounder Paralichthys olivaceus. Ph.D. Dissertation, Pukyong National University, Busan, KR.

Leung KY, Yeap IV, Lam TJ and Sin YM. 1994. Serum resistance as a good indicator for virulence in Aeromonas hydrophila strains isolated from diseased fish in south-east Asia. J Fish Dis 18, 511-518.

Martins ML, Mouriño JLP, Amaral GV, Vieira FN, Dotta G, Jatobá AMB, Pedrotti FS, Jerônimo GT, Buglione-Neto CC and PereiraJr G. 2008. Haematological changes in Nile tilapia experimentally infected with Enterococcus sp. Braz J Biol 68, 657-661.

Nieto TP, Toranzo AE and Barja JL. 1984. Comparison between the bacterial flora associated with fingerling rainbow trout cultured in two different hatcheries in the north-west of Spain. Aquaculture 42, 193-206

Pruzanski W, Leers WD and Wardlaw AC. 1973. Bactericidal and bacteriolytic activity of leukemic sera. Cancer Res 33, 2048-2053.

Qiao G. 2011. Microbiological and pathogenic characteristics of Vibrio scophthalmi isolated from olive flounder Paralichthys olivaceus. Ph.D. Dissertation, Pukyong National University, Busan, KR.

Qiao G, Lee DC, Woo SH, Li H, Xu DH and Park SI. 2012a. Microbiological characteristics of Vibrio scophthalmi isolates from diseased olive flounder Paralichthys olivaceus. Fish Sci 78, 853-863.

Qiao G, Li H, Xu DH and Park SI. 2012b. Modified a colony forming unit microbial adherence to hydrocarbons assay and evaluated cell surface hydrophobicity and biofilm production of Vibrio scophthalmi. J Bacteriol Parasitol 3, 130.

Ram Bhaskar B and Srinivasa Rao K. 1989. Influence of environmental variables on haematology and compendium of normal haematological ranges of milkfish, Chanos chanos (Forskal), in brackishwater culture. Aquaculture 83, 123-136.

Robertsen B, Rostad G, Engstad R and Raa J. 1990. Enhancement of non-specific disease resistance in Atlantic salmon Salmo salar L. by a glucan from Saccharomyces cerevisiae cell walls. J Fish Dis $13,391-400$

Sankaran K and Gurnani S. 1972. On the variation in the catalytic activity of lysozyme in fishes. Indian J Biochem Biophys 9, 162-165.

Secombes CJ. 1990. Isolation of salmonid macrophages and analysis of their killing activity. In: Techniques in Fish Immunology. Stolen JS, Fletcher TC, Anderson DP, Robertson BS and van Muiswinkel WB, eds. SOS Publications, Fair Haven, NJ, US, pp.137-154.

Wang YG, Zhang Z and Qing L. 2004. The main diseases of cultured turbot Scophthalmus maximus and their prevention and treatment. Mar Fish Res 25, 61-68.

Wiklund T and Dalsgaard I. 2002. Survival of Flavobacterium psychrophilum in rainbow trout Oncorhynchus mykiss serum in vitro. Fish Shellfish Immunol 12, 141-153.

Won KM and Park SI. 2008. Pathogenicity of Vibrio harveyi to cultured marine fishes in Korea. Aquaculture 285, 8-13. 